\title{
EVOLUTTVE PATTERN OF SCHISTOSOMIASIS AND LIFE-SPAN OF S. MANSONI IN PATIENTS IIVING IN NON-ENDEMIC AREA IN BRAZIL
}

\author{
J. Rodrigues Coura, Bodo Wanke, Nortợ de Figueiredo, and C.A. Argento **
}

\begin{abstract}
Out of 2484 patients harboring $\mathbf{S}$. mansoni seen in Rio de Janeiro, 1197 had been living permanently out of endemic area from one to 30 years, without any possibility of reinfection; $90.1 \%$ of these 1197 patients were first seen with hepato-intestinal schistosomiasis and only $9.9 \%$ with hepatosplenic form. $55 \%$ of them still had $\mathbf{S}$. mansoni active infection 6 years or more after they had left the endemic area and $26.5 \%$ remained infected for more than 10 years.

The patients with intestinal or hepato-intestinal schistosomiasis did not develop the most severe form whether they had been treated or not, and the hepatosplenic patients had a long time to deteriorate.
\end{abstract}

\section{INTRODUCTION}

The evolutive pattern of schistosomiasis although not well known seems to depend on the intensity of the infection $(3,8)$ and on the host reaction to it $(1)$. Different behaviours of different "strains" could give a good explanation for the individual pattern of the disease as showed in experimental study (9), but some epidemiological observations $(2,4,6,7)$ do not entirely support this possibility : On the other hand, the activity of the infection and consequently the egg load seems to play with the host reaction the most important role in the morbidity of the disease.

A follow-up of patients living out of endemic areas appeared to be a natural model for studies on $S$. mansoni life-span and human schistosomiasis patterns.

\section{CLINICAL OBSERVATIONS}

Two thousands four hundred and eighty four patients infected with $S$. mansoni were seen in the Department of Tropical Medicine in Rio de Janeiro University from 1960 to 1971 . The origin of the patients and the cilincal form when they first came to our out-patients is shown in Table I.

From the total of 2484 patients with schistosomiasis coming from twelve different States of Brazil to Rio de Janeiro city, $2157(86.8 \%)$ were first seen with intestinal or hepatointestinal form and $\mathbf{3 2 7}$ $(13 \%)$ with hepatosplenic form.

The average of hepatosplenic form in this group of patients seems to be very high $(13 \%)$ in comparison with the common rate we usually find in endemic areas in Brazil (less than $6 \%$ of hepatosplenic

* This work was supported by the "Conselho Nacional de Pesquisas" of Brazll and "Conselho de Pesquisa e Ensino para Graduados", Federal University of Rio de Janeiro. Part of this paper was presented to the Afro-Brazilian meeting on Schistosomíasis, Brasilia, Brasil, 10-12 of March, 1974.

* Department of Preventive Medicine, Medical School, Federal University of Rio de Janetro. (Caixa Postal, 1859).

Submitted to publication on $5 / 6 / 1974$. 
TABLE I - Origin and clinical form of 2484 patients with schistosomiasis.

\begin{tabular}{l|r|r|r|r|r}
\hline \multirow{2}{*}{ State of origin } & \multicolumn{2}{|c|}{ Hepatointestinal } & \multicolumn{2}{c|}{ Hepatosplenic } & Total \\
\cline { 2 - 6 } & No & $\%$ & No & $\%$ & \\
\hline & & & & \\
Pernambuco & 512 & 84.7 & 92 & 15.2 & 604 \\
Paraiba & 436 & 88.6 & 56 & 11.3 & 492 \\
Minas Gerais & 357 & 83.6 & 70 & 16.3 & 427 \\
Rahia & 273 & 90.3 & 29 & 9.6 & 302 \\
Sergipe & 230 & 89.8 & 26 & 10.1 & 256 \\
Alagoas & 205 & 85.4 & 35 & 14.5 & 240 \\
Espírito Santo & 70 & 86.4 & 11 & 13.5 & 81 \\
Rio Grande do Norte & 29 & 90.6 & 3 & - & 32 \\
Rio de Janeiro & 25 & 96.1 & 1 & - & 26 \\
Ceará & 11 & 84.6 & 2 & - & 13 \\
Maranhão & 5 & 83.3 & 1 & - & 6 \\
São Paulo & 4 & 80.0 & 1 & - & 5 \\
& & & & & \\
\hline \multicolumn{1}{c|}{ T O T A L } & 2157 & 86.8 & 327 & 13 & 2484 \\
\hline
\end{tabular}

form), but we may consider that those patients looked for an especial hospital for Tropical Diseases and some of them were just referred to it, because they had splenomegaly, therefore it was expected to have a larger number of severe cases.

\section{FOLIOW-UP OF PATIENTS WITH SCHISTOSOMIASIS LIVING IN A NON- -ENDEMIC AREA.}

Out of 2484 patients harboring $S$. mansoni observed in our Service, 1197 had been living permanently in a non-endemic area from one up to 30 years as follows in $\mathrm{Ta}$ ble II and graph I.

These ages varied from 4 to 63 years and $90.1 \%$ of them were first seen with intestinal or hepatointestinal schistosomiasis (spleen not palpable) and only $9.9 \%$ with hepatosplenic form.

As one can see in Table II, over $55 \%$ of the patients still had active infection 6 or more years after they had left the endemic area, but none of them evolved from the intestinal or hepatointestinal form to hepatosplenic form in the period of observation.

\section{FOLLOW-UP OF PATIENTS AFTER TREATMENT}

Five hundred and twenty nine patients with intestinal or hepatointestinal schistosomiasis who had been previously investigated were treated either with trivalent antimony or niridazole (Ambilhar) or hycanthone. Out of the 529 patientes treated, 346 were followed-up from six months to six years; 309 from them had parasitological cure and out of these $2.43(79 \%)$ had "clinical cure" or improved. However, the other 64 patients with parasitological cure remained with the same symptoms and only two became worse.

Thirty seven patients were found at the time of re-examination not to be parasitologicaly cured by treatment, but 14 of them $(38 \%)$ had "clinical cure" or improved in their symptoms as shown in Table III.

None of the 346 patients treated and followed-up for six months to six years developed enlargement of the liver and the spleen was never palpable, independent of whether the parasites had or not been cleared. 


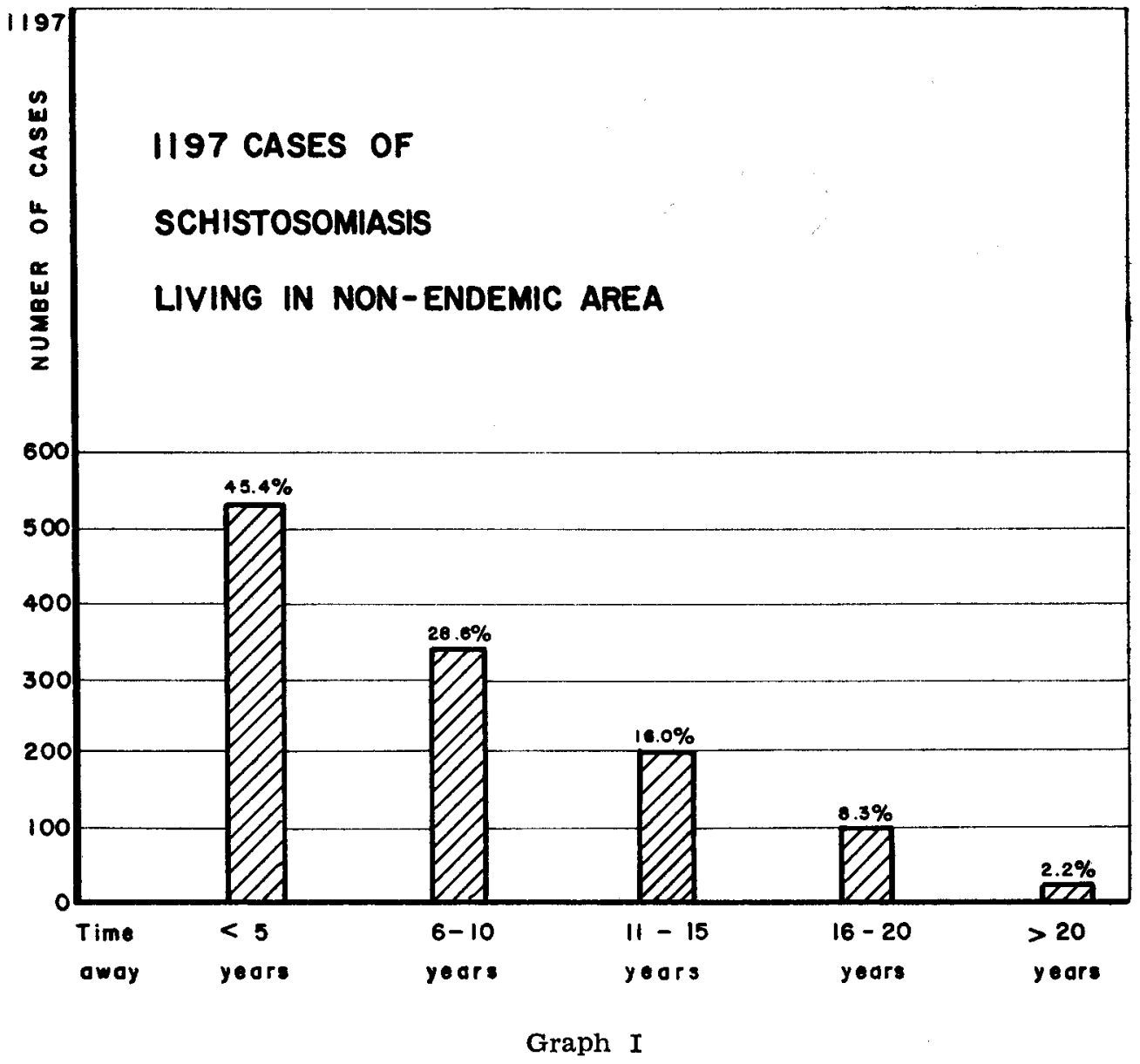

TABLE II - Length of time away from endemic area of Schistosomiasis and age groups of 1197 paients.

Time away from endemic area

5 years or less

6 to 10 years

11 to 15 years

16 to 20 years

21 to 30 years

\begin{tabular}{|r|r|r|r|r}
\multicolumn{2}{|c|}{ Patients } & \multicolumn{2}{|c|}{ Age of patients - (Years) } \\
\hline & $\%$ & Average & Minimum & Maximum \\
& & & & \\
\hline 544 & 45.4 & 24.86 & 6 & 58 \\
343 & 28.6 & 29.46 & 11 & 60 \\
193 & 16.0 & 33.97 & 15 & 56 \\
100 & 8.3 & 36.27 & 22 & 58 \\
27 & 2.2 & 42.89 & 27 & 50 \\
\end{tabular}


TABLE III - Correlation between symptoms and parasitological cure or therapeutic failure.

\begin{tabular}{l|c|c|c|c}
\hline \multirow{2}{*}{\multicolumn{1}{c|}{ Symptoms }} & \multicolumn{2}{|c|}{ Parasitological cure } & \multicolumn{2}{c}{ Therapeutic failure } \\
\cline { 2 - 5 } & No & $\%$ & No & $\%$ \\
\hline Cured & 150 & 48.6 & 4 & 10.8 \\
Improved & 93 & 30.1 & 10 & 27.0 \\
Unchanged & 64 & 20.7 & 23 & 62.2 \\
Deteriorated & 2 & 0.6 & 0 & 0.0 \\
\hline \multicolumn{1}{c}{ T O T A L } & 309 & $100 \%$ & 37 & 100 \\
\hline
\end{tabular}

OBSERVATIONS ON HEPATOSPLENIC FORM OF SCHISTOSOMIASIS

Seventy two patients with hepatosplenic form of schistosomiasis were investigated and treated, and followed-up from six months to nine years. Before treatment they were classified according to the size of the spleen in four grades:

Grade I: Spleen up to $2 \mathrm{~cm}$ below the left costal margin.
Grade II: Spleen from 2 to $5 \mathrm{~cm}$ below the left costal margin.

Grade III: Spleen from 5 to $8 \mathrm{~cm}$ below the left costal margin.

Grade IV: Spleen with more than $8 \mathrm{~cm}$ below the left costal margin.

On the basis of this classification and on the bleeding antecedents before treatment, the 72 patients were distributed as follows in Table IV.

TABLE IV - Correlation between the grade of splenomegaly and the bleeding antecedents in 72 patients with Schistosomiasis.

\begin{tabular}{c|c|c}
\hline $\begin{array}{l}\text { Classification } \\
\text { size of spleen }\end{array}$ & $\begin{array}{c}\text { Number of } \\
\text { cases }\end{array}$ & $\begin{array}{c}\text { Hematemesis and } \\
\text { or melena }\end{array}$ \\
\hline Grade I & 15 & 2 \\
Grade II & 11 & 0 \\
Grade III & 7 & 1 \\
Grade IV & 39 & $17(43.5 \%)$ \\
Total & 72 & 20 \\
\hline
\end{tabular}


Although the bleeding antecedents were observed in two patients with spleen of small size, the great majority of bleeding occurred in patients with big spleen.

A follow-up study was: made in $30 \mathrm{pa}$ - tients submitted to a shunting operation (splenorenal shunt) comparing the bleeding : rate before and after shunting as can be seen in the following table. (Table V).

TABLE V - Correlation of bleeding before and after shunting operation.

\begin{tabular}{l|c|c|c|c}
\hline $\begin{array}{c}\text { Esophagogastric } \\
\text { varices }\end{array}$ & $\begin{array}{l}\text { Before shunting } \\
\text { Number of cases }\end{array}$ & $\begin{array}{l}\text { After shunting } \\
\text { Number of cases }\end{array}$ & Deaths \\
\hline Bleeding & 17 & $4(*)$ & 1 \\
Non-bleeding & 13 & 26 & 1 \\
\hline Total & 30 & 30 & 1 \\
\hline
\end{tabular}

(*) One with active duodenal ulcer.

\section{CONCLUSIONS}

Based on their experience with patients living in a non-endemic area of schistosomiasis, the authors conclude:

1) Over $55 \%$ of patients with schistosomiasis still had active infection 6 or more years after they had left the endemic area and $26,5 \%$ remained infected for more than 10 years.

2) The life-span of $S$. mansoni in Brazil seems to be much longer than in Egypt and perhaps in Africa, based in our observations compared with those from Hairston (5).

3) Patients with intestinal or hepatointestinal schistosomiasis did not develop the most severe forms whether they had been treated or not.

4) Hepatosplenic patients had a long time to deteriorate. Bleeding was seldom related to mild splenomegaly but was quite commonly noted in patients with marked splenomegaly.

\section{$R E S U M O$}

Entre 2.484 portadores de esquistossomose estudados no Rio de Janeiro, 1.197 estavam afastados da área endêmica, permanentemente, de um a 30 anos. Apesar disso mais de 55\% deles ainda estavam com infecção ativa após 6 anos de afastamento, 26,5\% permaneciam infectados por mais de 10 anos e mais de $10 \%$ ainda estavam infectados depois de 15 anos de afastamento da área endêmica, o que demonstra a longa sobrevida e permanência da postura do S. mansoni no organismo humano, no Brasil, ao contrário das observaçóes de Hairston (5) no Egito, que avaliou o tempo médio da fecundidade (postura) da fêmea do $\mathrm{S}$. mansoni em 3 anos $e$ meio.

Dos 1.197 pacientes estudados $90,1 \%$ eram da forma intestinal ou hepato-intestinal e 9,9\% da forma hepato-esplênica. Nenhum paciente de forma in- 
testinal ou hepato-intestinal desenvolveu a forma hepato-esplênica, durante o período de observação fora da área endêmica o que demonstra uma parada na evolução da doença. possivelmente pela reduçâo progressiva da carga parasitária. Os pacientes da torma hepato-esplênica com baços não muito aumentados, tiveram uma evolução muito lenta e agravamento discreto e pouco freqüente durante o periodo de observaçāo, enquanto que os hepato-esplênicos com baços muito grandes (grau IV) tiveram hemorragias freqüentes. O padrão evolutivo dos portadores de esquistossomose fora da area endêmica parece diferente daquele observado na área endêmica $(7,8)$.

\section{REFERENCES}

1. ANDRADE, Z.A. - Hepatíc schistosomiasis. Morphological aspects. In Popper, H. \& Schaffner, P. "Progress in Liver Diseases". 2: 228-242, 1965.

2. BARBOSA, F. S. - Morbidade da esquistossomese. Rev. Bras. Malar. D. Trop. Número especial: 3-159, 1967.

3. CHEEVER, A.W. - A quantitative post-mortem study of Schistosomiasis mansoni in man. Am J. Trop. Med., 17: 38-64, 1968.

5. HAIRSTON, N.G. - On the Mathematical Analysis of Schistosoma Populations. Bull. Wld. Hlth. Org., 33: 45-62, 1965.

6. KATZ, N. \& BRENER, Z. - Evolução clínica de 112 casos de esquistossomose mansoni observados após 10 anos de permanência em focos en- dêmicos de Minas Gerais. Rev. Inst. Med. Trop. São Paulo, 8: 139-142, 1966.

7. KLOETZEL, $\mathbf{K}$. - Natural History and Prognosis of Splenomegaly in Schistosomiasis mansoni. Am. J. Trop. Med. \& Hyg. 13: 541-544, 1964.

8. PRATA, A. \& BINA, J.C. - Development of the hepatosplenic form of Schistosomiasis (A Study of 20 patients observed during a 5 years period). Gaz. Med. Bahia, 68: 49-60, 1968.

9. WARREN, K.S. - A comparison of Puerto Rican, Brazilian, Egyptian and Tanzanian strains of Schistosoma mansoni in mice: penetration of cercariae, maturation of Schistosomes and production of liver disease. Trans. R. Soc. Trop. Med. Hyg., 61: 795$-802,1967$. 